\title{
Polyphenol composition and technological characteristics of the coloured whey from various origin
}

\author{
Olena Grek, Tetiana Pshenychna, \\ Larisa Chubenko, Olena Onopriichuk
}

\author{
National University of Food Technologies, Kyiv, Ukraine
}

Keywords:

Coagulation

Coloured whey

Colouration

Polyphenol

Article history:

Received

17.01.2020

Received in revised

form 11.08.2020

Accepted

27.12.2020

\section{Corresponding}

author:

Olena Onopriichuk

E-mail:

olena.onopriychuk@

gmail.com

DOI:

$10.24263 / 2304-$

974X-2020-9-4-9

\section{Abstract}

Introduction. The aim of this work was to determine the polyphenol composition and technological characteristics of coloured whey from various origin - obtained by milk proteins coagulation with traditional berry raw materials and wild herbs.

Materials and methods. Coloured whey is obtained as a result of thermo acid coagulation of milk proteins by plant origin coagulants. The identification and quantitative determination of polyphenol compounds in the coloured whey samples has been carried out by high performance liquid chromatography. The solids content in the coloured whey has been investigated by the refractometric method and optical dense for the colouration and turbidity of the coloured whey - by the colorimetric method.

Results and discussion. The whey samples had violet and green shades, respectively, due to the presence of specific coloured substances, including various polyphenols, which are a component in black currant berries and chlorophyll in plantain juice. The content of the above-mentioned compounds in whey after milk proteins coagulation with Plantago major L. juice and cavitation processed blackcurrant paste are 324.43 and $265.49 \mathrm{mg} / \mathrm{L}$, respectively. With an increase in the amount of plant coagulant for thermo acid coagulation of milk proteins from 5 to $11 \%$, the optical dense value for turbidity of coloured whey decreases by 0.40 and 0.41 cond. units and for the colouration, on the contrary, increase by 0.17-0.19 cond. units for coloured whey after milk proteins coagulation with Plantago major L. juice and blackcurrant paste, respectively. Dry matters weight ratio in coloured whey has been fixed at the level of $6.80-8.55 \%$. The protein content was $0.96-$ $1.33 \%$, depending on the amount of plant origin coagulant during thermo acid milk coagulation. The coloured whey, obtained after the milk proteins coagulation by plant coagulants in the amount of $8 \%$ and $11 \%$ had a lower protein content by $0.32-0.45 \%$, compared to the control sample. This confirms the complex casein and milk whey proteins coagulation by organic acids of the cavitation processed blackcurrant paste and the active complex (proteases and organic acids) of plantain juice.

Conclusions. Coloured whey samples have improved taste, colour characteristics and increased nutritional value, which makes it widely used in whey beverages with or without additional processing. 


\section{Introduction}

Research of various additional sources of milk raw materials, including milk whey, in order to develop full-fledged, available and safe drinks, is actual [1]. However, the use of whey for various drinks needs to be adjusted in the recipe to weaken whey tones in taste and smell [2].

In the beverage industry, whey is combined with fruit and vegetable juices, fruit and berry purees and herbal extracts to give the product not only a pleasant and refreshing effect, but also preventive properties. Depending on the beverage type, processed or unprocessed whey is used, as well as condensed or dry concentrates with the fruit and aromatic fillers addition. For example, in Germany, whey is used to prepare tasty beverages containing 80 $90 \%$ whey and $10-20 \%$ strawberry and peach juice. Similar beverages are made with the addition from 7 to $20 \%$ grapefruit or other juice. The traditional Iranian beverage «Dough» is made from milk whey pasteurized at a temperature of $74-76^{\circ} \mathrm{C}$ and then cooled to $40-42$ ${ }^{\circ} \mathrm{C}$ with the addition of $2.5 \%$ dessert yogurt. In Austria, a popular drink with a long storage period is a mixture of $50 \%$ whey, $40 \%$ fermented milk and $10 \%$ fruit juice $[3,4]$.

The above-mentioned developments are focused on correcting the chemical composition and sensory characteristics of whey in order to enrich and increase the nutritional value in beverages based on it.

For the manufacturer, an important advantage of adding fruit and berry fillers is the bright taste and fresh flavor in the final product. In addition, the filler presence with an appropriate chemical composition eliminates the necessity to add flavoring matter, coloring agents and some types of stabilizers [5].

A promising direction in the technology for the enriched dairy products production with functional properties is using of coloured whey obtained as a result of complex milk processing into protein concentrates in the presence of plant coagulants. In particular, the plant using as technological components allows to change the sensory characteristics in the milk whey, due to different taste shades and colours, and also to regulate the composition of biologically active substances [6].

It is recommended to use intensely coloured herbal compositions in order to improve the sensory characteristics of whey-based products. This is due to the fact, that in an acidic environment caused by whey lactic acid, plant systems acquire changes in colour intensity caused by the bioflavonoids dissociation [7].

There are no studies to determine the optical dense for colouration and turbidity, as well as coloured substances and polyphenol composition in the coloured whey obtained after the milk proteins coagulation by plant coagulants, which caused its natural color.

The use of the plant raw materials, both berry and herbal, as a coagulant for thermo acid coagulation of milk proteins will contribute to the addition of organic complex compounds in whey and the formation of original sensory characteristics in the separation products. This will exclude the use of artificial coloring agents and flavors in the future [8,9].

The aim of this work was to determine the polyphenol composition and technological characteristics of coloured whey from various origin - obtained by milk proteins coagulation with traditional berry raw materials and wild herbs. In addition, sensory characteristics, dry matters weight ratio, including protein, and active acidity of from various origin have been determined. 


\section{Materials and methods}

\section{Materials}

Coloured whey, obtained in the protein concentrates production by thermo acid coagulation of milk proteins with plant coagulants - berry paste and plantain juice. Coloured whey was obtained in two methods during thermo acid coagulation of milk proteins using as a coagulant - cavitation processed blackcurrant paste and Plantago major L. juice. According to the first method, a berry coagulant with an active acidity of $3.0 \pm 0.2 \mathrm{pH}$ was added to heated milk at a temperature of $(75 \pm 1){ }^{\circ} \mathrm{C}$ in an amount of 5 to $11 \%$, slightly mixed and kept $(2 \pm 1)$ min until a clot formed. The combined effect of high temperatures and acidic reagents on milk proteins leads to their maximum coagulation. The coagulation process was visually established by the intensive formation of protein flakes and whey release, that has a natural violet colour of the coagulant [10].

According to the second method, directly squeezed juice from the ground part of Plantago major L. was used as a coagulant in an amount from $5 \%$ to $11 \%$ with the following indicators: dry matters $-4.55 \pm 0.23 \%, \mathrm{pH}-5.85 \pm 0.18$. The juice was added to milk at a coagulation temperature of $55-60{ }^{\circ} \mathrm{C}$ and held for $45-60 \mathrm{~min}$. Then the temperature was increased to $90-95^{\circ} \mathrm{C}$, slightly mixed and held for $2-3$ minutes until a clot was formed. Then the clot was pressed for $15 \pm 2$ min to separate the whey [11].

As a result, about $80 \%$ of whey was obtained from volume of milk raw materials in the protein concentrates manufacture by both methods. Coloured whey has been sent to determine the content of polyphenol compounds, sensory, physical and chemical indicators.

\section{origin \\ Determination of the polyphenol composition in the coloured whey from various}

The determination was carried out by high-performance liquid chromatography (HPLC) using system Prominence LC-20 Shimadzu (Japan). The substances identification in the coloured whey extracts was performed by comparing the retention time and spectral characteristics of the test substances with similar characteristics of the standards according to the method identification of polyphenols. Chromatography was performed at 225, 255, 286 and $350 \mathrm{~nm}$ [12]. For accurate identification of the test substances to specific polyphenols groups, the following regulatory documents were used: chlorogenic and caffeic acids (phenolic acids), catechin (catechins), flavonols myricetin, quercetin and rutin, flavanones naringenin, naringin, hesperinidin, and protestin cyanidine (anthocyanins) (Sigma-Aldrich, Germany). The identification characteristics of these standards were obtained under the above-mentioned chromatography conditions [13]. The "peak area-standard content" calibration dependences had a linear form with an accuracy of at least $r^{2}=0.994$.

\section{Determination of colouration and turbidity of the coloured whey from various origin}

Samples of milk whey from various origin have a natural colour and turbidity, therefore, we used for research an adapted method for determining indicators in soft beverages. This method is based on optical dense determination and comparison with the corresponding standards: coloured solutions for colouration and suspension for turbidity.

The optical dense determination was carried out by the colorimetric method [14]. The value of optical dense $\mathrm{D}_{\text {gen }}$ consists of $\mathrm{D}$ due to the colouration caused by the coloring agents, 
and $\mathrm{D}_{\mathrm{t}}$ due to the turbidity caused by the proteins presence that scatter the light flux. When colouration determination, it is necessary to have a total absence of foreign particles with a radius of $0.4-0.8$ microns or more, which contribute to light scattering. Therefore, to prepare the samples for analysis, the coloured whey was filtered.

The research was carried out using a Helios Omega spectrophotometer (Thermo Scientific Spectronic, USA). The spectrophotometer is designed for measure in individual sections of the wave-length range $315-980 \mathrm{~nm}$, which are formed by light filters, transmission coefficients, optical dense of liquid solutions, and measuring the substances concentration in solutions after preliminary determination of the calibration characteristic. Cuvettes with a test solution (coloured whey) and control solution (milk whey), in relation to which the measurements were carried out, were installed in the cuvette compartment. The necessary light filter and photodetector were installed, the sample compartment cover was closed, and the studies were carried out. On a digital display, values were obtained that correspond to the optical dense of coloured whey.

The content of dry matters in the coloured whey was investigated by the refractometric method according to the light refractive indices [15]. First, check the correctness of the refractometer readings for distilled water at a temperature of $20 \pm 0.1{ }^{\circ} \mathrm{C}$. With one or two water drops applied to the prism, the refractometer reading should be zero. The refractometer prism is wiped off with a paper filter and one or two drops of a test whey sample are applied. On the right refractometer scale, the content of dry matters was found, which coincides with the distribution boundary of the dark and light fields.

The active acidity in the coloured whey was determined potentiometrically [16] on a Sartorius PB-20 universal $\mathrm{pH}$ meter. To determine the $\mathrm{pH}, 40 \mathrm{~cm}^{3}$ of coloured whey was taken into the beaker, the electrodes are immersed in the beaker and after 10-15 seconds the readings of the device are recorded. The electrodes are rinsed with distilled water and wiped off with filter paper after each measurement.

\section{Statistical analysis}

Data were expressed as means \pm standard deviations for triplicate determination. Statistical analysis was performed using Microsoft Excel 2007. Differences were considered to be significant at validity of $\alpha=0.95$.

\section{Results and discussion}

\section{Determination of sensory characteristics and polyphenol composition of the coloured whey from various origin}

The sensory characteristics of the coloured whey obtained as a result of the thermo acid coagulation of milk proteins by plant coagulants - blackcurrant paste and Plantago major $\mathrm{L}$. juice, is given in Table 1 . 
Sensory characteristics of the coloured whey from various origin

\begin{tabular}{|c|c|c|c|}
\hline \multirow[t]{2}{*}{ Indicator name } & \multicolumn{3}{|c|}{$\begin{array}{c}\text { Amount of blackcurrant paste during thermo acid } \\
\text { coagulation of milk proteins, } \%\end{array}$} \\
\hline & 5 & 8 & 11 \\
\hline $\begin{array}{l}\text { Consistency and } \\
\text { appearance }\end{array}$ & \multicolumn{3}{|c|}{ Homogeneous, flowing liquid, slight sediment is allowed } \\
\hline Taste and flavor & $\begin{array}{l}\text { Clean, lactic, without } \\
\text { foreign tastes and } \\
\text { smells }\end{array}$ & \multicolumn{2}{|c|}{$\begin{array}{l}\text { Slightly acid, with a berry coagulant } \\
\text { taste and flavor }\end{array}$} \\
\hline \multirow[t]{3}{*}{ Colour } & $\begin{array}{l}\text { Light violet, uniform } \\
\text { in volume }\end{array}$ & $\begin{array}{l}\text { Violet, uniform in } \\
\text { volume }\end{array}$ & $\begin{array}{l}\text { Intense violet, } \\
\text { uniform in } \\
\text { volume }\end{array}$ \\
\hline & \multicolumn{3}{|c|}{$\begin{array}{l}\text { Amount of Plantago major L. juice during thermo acid } \\
\text { coagulation of milk proteins, } \%\end{array}$} \\
\hline & 5 & 8 & 11 \\
\hline $\begin{array}{l}\text { Consistency and } \\
\text { appearance }\end{array}$ & $\begin{array}{l}\text { Turbid liquid, with } \\
\text { visible protein } \\
\text { inclusions, which in } \\
\text { the time following } \\
\text { coagulates }\end{array}$ & \multicolumn{2}{|c|}{$\begin{array}{l}\text { Homogeneous, clear liquid, with a } \\
\text { small sediment amount }\end{array}$} \\
\hline Taste and flavor & $\begin{array}{l}\text { Lactic, with a barely } \\
\text { there herbal flavor }\end{array}$ & \multicolumn{2}{|c|}{$\begin{array}{l}\text { Slightly bitter, with a pleasant herbal } \\
\text { smell and taste }\end{array}$} \\
\hline Colour & $\begin{array}{l}\text { Mostly white, with a } \\
\text { barely there greenish } \\
\text { cast }\end{array}$ & $\begin{array}{l}\text { Green, uniform in } \\
\text { volume }\end{array}$ & $\begin{array}{l}\text { Intense green, } \\
\text { uniform in } \\
\text { volume }\end{array}$ \\
\hline
\end{tabular}

The obtained whey samples had the corresponding shades, which is due to the presence of specific colour substances - flavonoid pigments and chlorophyll in black currant berries and plantain juice [17].

In order to determine the transition degree of colouring compounds, it was analyzed the polyphenol composition in plant coagulants - cavitation processed blackcurrant paste, Plantago major L. juice, protein-plant concentrates and coloured whey from various origin.

The total polyphenols content in the studied samples has been determined by summing up the substances content, that were found in the peaks range of flavonoids, non-flavonoids, and phenolic acids on chromatograms.

The flavonoids content in all studied samples was equal to the substances content that are similar to the flavonoids standards (phenolic acids, catechins, flavonoids, flavonones and flavones), with the exception of catechin-like substances. The polyphenol composition of whey correlates with the composition of specially processed blackcurrant paste and Plantago major L. juice, respectively. The research results have been analyzed in comparison with the control samples - plant coagulants. Their transition degree to separation products - protein concentrates and whey of various colours has been determined. The research results are presented in Table 2 . 
Table 2

Total composition and polyphenols content in samples of the coloured whey from various origin

\begin{tabular}{|c|c|c|}
\hline \multirow{3}{*}{ Polyphenols group } & \multicolumn{2}{|c|}{ Polyphenols content, mg/l } \\
\hline & \multicolumn{2}{|c|}{$\begin{array}{c}\text { Coloured whey } \\
\text { after milk proteins coagulation by }\end{array}$} \\
\hline & $\begin{array}{l}\text { Cavitation processed } \\
\text { blackcurrant paste }\end{array}$ & $\begin{array}{l}\text { Plantago major } \mathrm{L} . \\
\text { juice }\end{array}$ \\
\hline Phenolic acids & 2.13 & 0.07 \\
\hline $\begin{array}{l}\text { Catechins, including certain } \\
\text { substances: }\end{array}$ & 104.13 & 33.69 \\
\hline - catechin & 2.16 & 6.82 \\
\hline Catechin-like * & - & 166.53 \\
\hline $\begin{array}{l}\text { Flavonols, including certain } \\
\text { substances: }\end{array}$ & 11.67 & \\
\hline $\begin{array}{l}\text { - glycosides of myricin } \\
- \text { rutin }\end{array}$ & 3.20 & 1.01 \\
\hline - quercetin & 0.23 & \\
\hline $\begin{array}{l}\text { Flavanones, including certain } \\
\text { substances: }\end{array}$ & 11.87 & 1.04 \\
\hline- naringin & 1.17 & 0.13 \\
\hline - hesperidin & & 0.91 \\
\hline $\begin{array}{l}\text { Flavones, including certain } \\
\text { substances: }\end{array}$ & - & 0.31 \\
\hline - glycosides of luteolin & & 0.31 \\
\hline $\begin{array}{l}\text { Anthocyanins, including certain } \\
\text { substances }\end{array}$ & 125.09 & \\
\hline - delphinidin-3-O-glucoside & 16.87 & - \\
\hline - cyanidin-3-O-galactoside & 17.09 & \\
\hline - delphinidin-3-O-arabinoside & 33.70 & \\
\hline Unidentified & 10.60 & 120.72 \\
\hline Amount of polyphenols & 265.49 & 324.43 \\
\hline
\end{tabular}

* - catechin-like - polyphenols whose peaks are located outside the area of the catechin peaks, but with the spectral catechins characteristics.

According to the obtained results in Table 2, flavonols are represented by glycosides myricithin, rutin and quercetin; naringin and hesperidin are found in flavonones [18]. The flavones identified in the coloured whey after milk proteins coagulation by the Plantago major L. juice have the smallest amount and are represented by luteolin and its glycosides. The content of phenolic acids is fixed at $2.13 \mathrm{mg} / \mathrm{l}$ for coloured whey after milk proteins coagulation by blackcurrant paste and $0.07 \mathrm{mg} / \mathrm{l}$ for whey after milk proteins coagulation by Plantago major L. juice.

In total, 12 flavonoid class compounds were identified in the coloured whey obtained after the milk proteins coagulation by Plantago major L. juice, which are 10 less than their content in the plantain juice. This is probably due to the fact that a significant amount of polyphenol compounds from juice was transferred to milk-protein concentrate during denaturation. 
The content of polyphenol compounds in coloured whey after the milk proteins coagulation by Plantago major L. juice and cavitation processed blackcurrant paste is 324.43 and $265.49 \mathrm{mg} / \mathrm{l}$, respectively. As a comparison, according to literature data, the polyphenols content in plantain juice was within $1411.13 \mathrm{mg} / \mathrm{l}$, and in blackcurrant paste - $690 \mathrm{mg} / 1$ [19].

The transition degree of polyphenol compounds into coloured whey after the milk proteins coagulation by Plantago major L. juice is $23 \%$ of their total amount, about $77 \%$ of polyphenols, including $74 \%$ of flavonoids, remain in protein-plant concentrates. Probably, this effect is likely due to the polyphenols interaction with proteins and their attachment to the globule surface at the unfolding time of the polypeptide chain due to the formation of a hydrogen bond between the polyphenol hydroxyl group and the carbonyl group of the protein molecule [5].

Similarly, the transition degree of polyphenol compounds into coloured whey after the milk proteins coagulation by cavitation processed blackcurrant paste has been calculated, which was fixed at $42 \%$. About $53 \%$ of polyphenol compounds, including anthocyanins, remain in concentrates, which is due to the weight loss correlation of the concentrate during technological operations, such as pressing and forming.

By their chemical nature, anthocyanins are representatives of natural polyphenol compounds of the flavanoids class with antimicrobial activity [20,21]. Therefore, their content in the coloured whey was additionally analyzed.

Coloured whey contains all known anthocyanins: delphinidin-3-O-galactoside, delphinidin-3-O-glucoside, cyanidin-3-O-galactoside, delphinidin-3-O-arabinoside, cyanidin-3-O-glucoside, petunidin -3-O-galactoside, peonidin-3-O-glucoside, malvidin-3-Oarabinoside, etc. and complete, respectively, $47 \%$ of the total polyphenols content in the samples.

\section{Determination of optical dense for colouration and turbidity of the coloured whey from various origin}

Optical dense indices for characterizing the turbidity and colouration of the coloured whey from various origin are important for determining the using ways for technological purposes. The optical dense, which characterizes the turbidity and colouration of the coloured whey is given in Table 3.

Table 3

Optical dense which characterizes the turbidity and colouration of the coloured whey $(\mathrm{n}=3, \mathrm{p} \leq 0.05)$

\begin{tabular}{|c|c|c|c|c|}
\hline \multirow{2}{*}{$\begin{array}{c}\text { Amount of plant } \\
\text { coagulant during } \\
\text { thermo acid }\end{array}$} & \multicolumn{3}{|c|}{ Coloured whey after milk proteins coagulation by } \\
\cline { 2 - 5 } $\begin{array}{c}\text { coagulation of } \\
\text { milk proteins, } \%\end{array}$ & \multicolumn{2}{|c|}{$\begin{array}{c}\text { Cavitation processed } \\
\text { blackcurrant paste }\end{array}$} & \multicolumn{2}{c|}{ Plantago major L. juice } \\
\cline { 2 - 5 } & $\mathbf{D}_{\text {t, cond. unit }}$ & D, cond. unit & Dt, cond. unit & D, cond. unit \\
\hline 5 & $1.877 \pm 0.037$ & $1.065 \pm 0.021$ & $1.953 \pm 0.058$ & $1.127 \pm 0.034$ \\
\hline 8 & $1.515 \pm 0.045$ & $1.169 \pm 0.023$ & $1.625 \pm 0.049$ & $1.233 \pm 0.037$ \\
\hline 11 & $1.466 \pm 0.044$ & $1.259 \pm 0.025$ & $1.547 \pm 0.046$ & $1.295 \pm 0.039$ \\
\hline Control samples* & $1.511 \pm 0.045$ & $1.204 \pm 0.024$ & $1.605 \pm 0.048$ & $1.255 \pm 0.038$ \\
\hline
\end{tabular}

*Coloured whey beverages "Aktual" (with watermelon-melon and neon mojito flavor) produced by LLC «Danone Dnipro» 
The optical densy of the coloured whey samples obtained after the milk proteins coagulation by blackcurrant paste during determination the turbidity and colouration of the whey ranged from 1.46 to 1.88 cond. units and 1.06-1.26 cond. units, respectively. Optical dense indices before and after filtration for coloured whey obtained as a result of milk coagulation by Plantago major L. juice is fixed at the level of $1.55-1.95$ cond. units and $1.13-1.29$ cond. Units

According to the results in Table 3, with an increase in the amount of plant coagulant for thermo acid coagulation of milk proteins from 5 to $11 \%$, the optical dense value for turbidity $\left(D_{t}\right)$ of coloured whey from various origin decreases by 0.40 and 0.41 cond. units for coloured whey after milk proteins coagulation with Plantago major L. juice and blackcurrant paste, respectively. This effect is due to the mechanism of thermo acid coagulation of milk proteins and an increase in the casein transition degree and the maximum amount of whey proteins into protein-plant concentrates [22].

Optical dense indicators, which characterize the colouration, on the contrary, increase with an increase in the amount of coagulant from $5 \%$ to $11 \%$ during thermo acid coagulation by $0.17-0.19$ cond. units for coloured whey after milk proteins coagulation by Plantago major L. juice and blackcurrant paste, respectively. This is, probably, due to an increase in the transition degree of specific coloured substances - polyphenolic compounds, including flavanoids and anthocyanins, of plant raw materials into a protein clot and whey [23]. However, almost all of these values have variance from the control samples - whey beverages of the corresponding colour up to $5 \%$.

\section{Determination of the dry matters weight ratio and active acidity in the whey from various origin}

Whey contains $50 \%$ of the dry matters of whole milk, almost all milk sugar and about $30 \%$ of milk proteins. The change in the dry matters weight ratio in coloured whey depending $\mathrm{n}$ the amount and type of plant coagulant is shown in Figure 1.

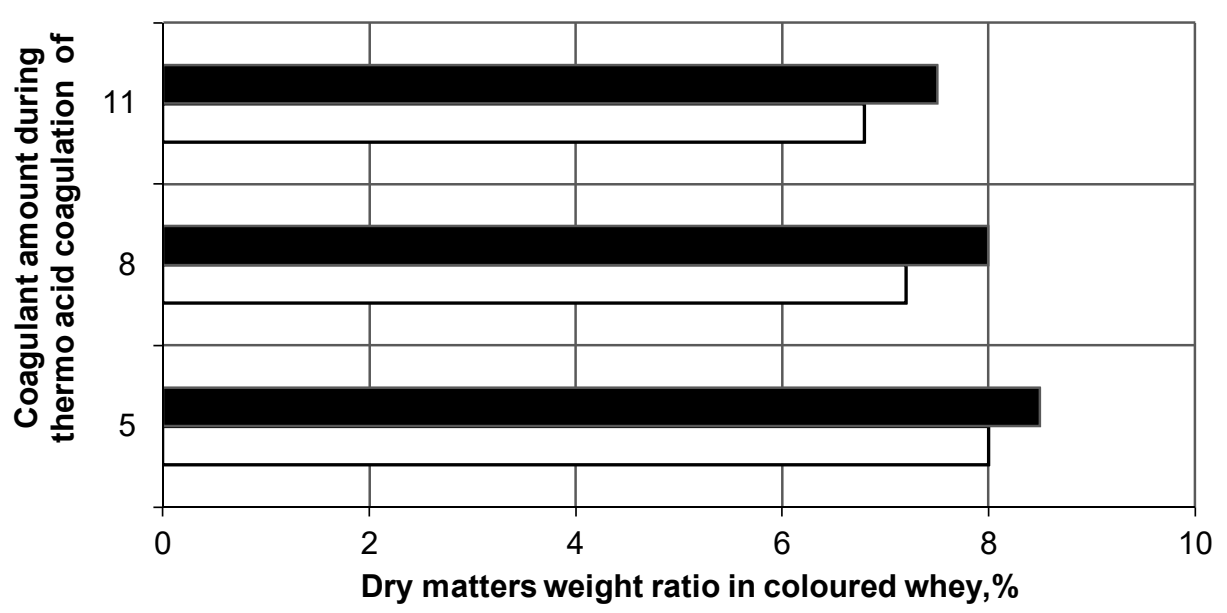

-Whey after milk proteins coagulation by Plantago major L. Juice $\square$ Whey after milk proteins coagulation by blackcurrant paste

Figure 1. Dry matters weight ratio in coloured whey depending on the amount and type of plant coagulant 
Dry matters weight ratio in coloured whey ranges from 6.80 to $8.55 \%$, including $0.96-$ $1.33 \%$ of protein and depends on the amount of plant coagulant during thermo acid coagulation of milk proteins. Thus, the protein content in coloured whey was in average at $1.33 \pm 0.04 \%$ after thermo acid coagulation using $5 \%$ plant coagulant, $1.01 \pm 0.03 \%-8 \%$ coagulant, and $0.96 \pm 0.04 \%$ with the addition of $11 \%$ plant raw materials. This indicates a more complete coagulation and transition of milk proteins into a protein-plant clot [24].

The control sample obtained as a result of the milk proteins coagulation by whey with titrated acidity not less than $160^{\circ} \mathrm{T}$ had a protein content of $1.35 \%$. Compared to the control sample, coloured whey obtained after thermo acid coagulation of milk proteins with plant coagulant in the amount of $8 \%$ and $11 \%$ had a lower protein content by $0.34-0.39 \%$. This confirms the complex casein and whey proteins coagulation by organic acids of blackcurrant paste and an active complex of plantain juice.

Dependence of the active acidity in coloured whey on the amount and type of plant coagulant during thermo acid coagulation of milk proteins is shown in Figure 2.

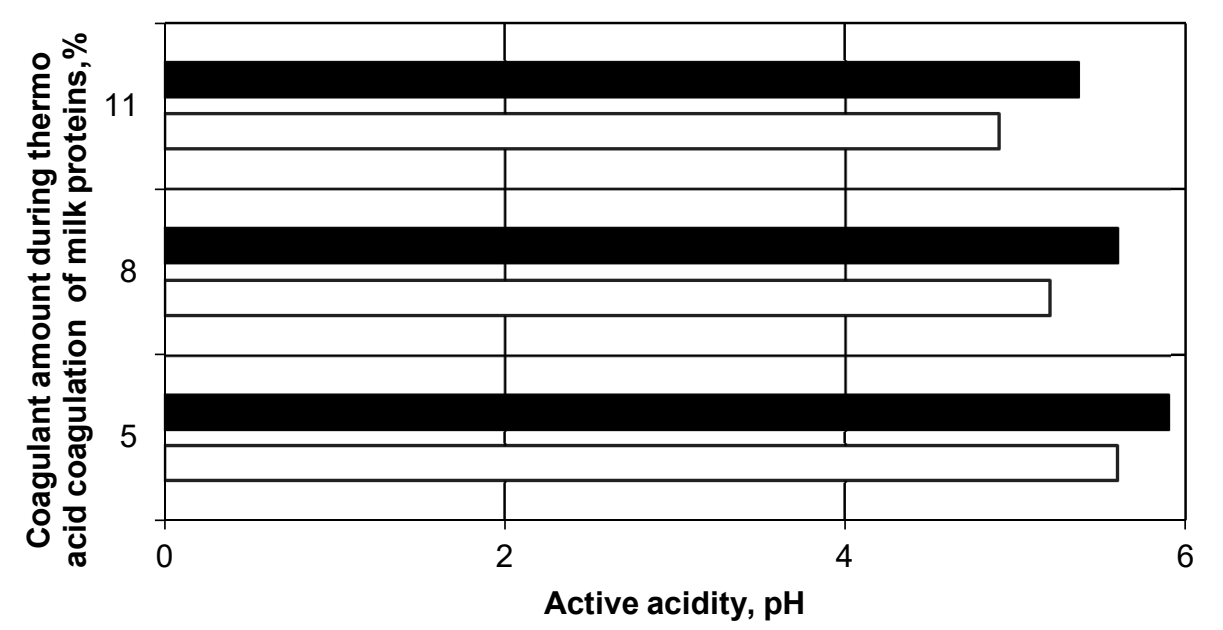

Whey after milk proteins coagulation by Plantago major L. juice $\square$ Whey after milk proteins coagulation by blackcurrant paste

Figure 2. Dependence of the active acidity in coloured whey on the amount and type of plant coagulant

The histogram shows the $\mathrm{pH}$ value in the whey samples decreases in proportion to the increase in the amount of plant coagulant for thermo acid coagulation of milk proteins. At this stage, it can be observed, the amount and type of plant coagulant affects the active acidity, changing it to the acidic side by 0.55 and $0.70 \mathrm{pH}$ when using $11 \%$ milk protein coagulant in the form of Plantago major L. juice and blackcurrant paste, respectively.

The value decrease of active acidity occurred slowly during storage period of whey samples at a temperature of $(4 \pm 2){ }^{\circ} \mathrm{C}$ for 72 hours. During 48 hours of whey storage period, active acidity in the control sample decreased by $0.32 \mathrm{pH}$ compared to the initial value of $5.91 \mathrm{pH}$, in coloured whey after protein coagulation by Plantago major L. juice and 
cavitation cavitation blackcurrant paste by an average of 0.20 and $0.25 \mathrm{pH}$, respectively. An active decrease was observed in the samples obtained after the milk proteins coagulation by blackcurrant paste in an amount of $11 \%$, that for 72 hours of storage period was at $4.65 \mathrm{pH}$. Coloured whey from various origin retained its sensory characteristics, including the colour intensity, at all stages of storage period at a temperature of $(4 \pm 2)^{\circ} \mathrm{C}[25]$.

Scope of whey applicability is usually limited due to high acidity, deficiencies in sensory characteristics (salty and sour taste, pronounced whey flavor). In practice, for the whey deoxidation, which has a $4.50-5.00 \mathrm{pH}$, various chemical substances are used (solutions of ammonia, sodium hydroxide, etc.) [26]. Soda solution (sodium bicarbonate) is chemically safe, available and traditionally used in the food industry to neutralize (deoxidize) whey.

Coloured whey obtained after the milk proteins coagulation by cavitation processed blackcurrant paste and Plantago major L. juice can be used with or without additional processing (filtration, deoxidation) as a base and prescription component for whey beverages, such as pasteurized whey, pasteurized whey with sugar, and etc. This makes it possible to completely exclude the use of food coloring agents and flavoring matter of artificial origin in their composition. These technologies are classical and do not require additional parameters specification.

\section{Conclusion}

1. Coloured whey obtained after milk proteins coagulation by Plantago major L. juice and cavitation processed blackcurrant paste is characterized by polyphenol compounds content at the level of 324.43 and $265.49 \mathrm{mg} / \mathrm{l}$, respectively, which has a positive effect on its nutritional value and sensory characteristics. Whey had, respectively, green and violet colour, which is characteristic for raw materials that contain flavonoids and anthocyanins.

2. Optical dense which characterizes the turbidity and colouration for samples of coloured whey obtained after milk proteins coagulation by cavitation processed blackcurrant paste ranged within 1.46-1.88 cond. units and 1.06-1.26 cond. units, and for the coloured whey obtained as a result of milk coagulation by Plantago major L. juice was fixed at the level of $1.55-1.95$ cond. units and 1.13-1.29 cond. units, respectively.

3. The obtained results on the dry matters content at the level $(6.80-8.55 \%)$, including protein $(0.96-1.33 \%)$ and active acidity $(4.90-5.90 \mathrm{pH})$, indicate the practicability of using in beverage formulations - coloured whey obtained as a result of thermo acid coagulation of milk proteins by plant coagulant in an amount of $8 \%$ without additional processing. When using whey obtained after coagulation by a coagulant in the amount of $11 \%$ - expose it to deoxidation, and in the amount of $5 \%$ - to filtration.

\section{References}

1. Skryplonek K., Dmytrów I., Mituniewicz-Małek A. (2019), Probiotic fermented beverages based on acid whey, Journal of Dairy Science, 102(9), pp. 7773-7780.

2. Carter B.G., Foegeding E.A., Drake M. A. (2020), Invited review: Astringency in whey protein beverages, Journal of Dairy Science, 103(7), pp. 5793-5804.

3. Musiichuk O. (2008), Perspektyvy vykorystannia produktiv pererobky molochnoi syrovatky, Tovary i rynky, 1, pp. 78-83. 
4. Souza T. S. P., Luna A. S., Barros D.B., Pimentel T. C., Pereira E.P.R., Guimarães J.T., Esmerino E.A., Freitas M.Q., Costa R.G.B., Silva M.C., Quitério S.L., Raices R.S.L., Cruz A. G. (2019), Yogurt and whey beverages available in Brazilian market: Mineral and trace contents, daily intake and statistical differentiation, Food Research International, 119, pp. 709-714.

5. Chevalier L.M., Riouxa L.E., Angers P., Turgeon S.L. (2019), Study of the interactions between pectin in a blueberry puree and whey proteins: Functionality and application, Food Hydrocolloids, 87, pp. 61-70.

6. Chabanova O.B., Kochmar L.P., Chabanova A.A. (2012), Razrabotka tekhnologii pityevykh syvorotochnykh napitkov $\mathrm{s}$ ispolzovaniyem naturalnykh sokov, Kharchova nauka $i$ tekhnolohiia, 2(19), pp. 48-51.

7. Souza F.P., Balthazar C.F., Guimarães J.T., Pimentel T.C., Esmerino E.A., Freitas M.Q., Raices R.S., Silva M.C., Cruz A.G. (2019), The addition of xyloligoosaccharide in strawberry-flavored whey beverage, LWT Food Science and Technology, 109, pp. 118-122.

8. Evdokimov I.A., Volodin D.N. (2016), Sovremennoye sostoyaniye i perspektivy pererabotki molochnoy syvorotki, Pererabotka moloka, 8(203), pp. 10-13.

9. Janiaski D.R., Pimentel T.C., Cruz A.G., Prudencio S.H. (2016), Strawberry-flavored yogurts and whey beverages: What is the sensory profile of the ideal product?, Journal of Dairy Science, 99 (7), pp. 5273-5283.

10. Grek O., Onopriichuk O., Pshenychna T. (2017), Rationalization of the parameters of milk proteins' thermo acid coagulation by berry coagulants, Food and Environment Safety, 1(16), pp. 47-53.

11. Grek O.V., Krasulya O.O., Chubenko L.M., Tymchuk A.V. (2018), The investigation of the potentional comlex from Plantago major to coagulate milk proteins, Food and Environment Safety, 2(17), pp. 165-175.

12. Hodakov I.V., Makarenko O.A. (2010), Vysokoeffektivnaya zhidkostnaya khromatografiya $\mathrm{v}$ issledovanii rastitelnykh polifenolov, Vestnik stomatologii, 5, pp. 59-60.

13. Lu X.F., Zhou Y., Ren Y.P., Zhang J. (2019), Improved sample treatment for the determination of flavonoids and polyphenols in sweet potato leaves by ultra performance convergence chromatography-tandem mass spectrometry, Journal of Pharmaceutical and Biomedical Analysis, 169, pp. 245-253.

14. Dedegkaev A.T., Afonin D.V., Meledina T.V. (2006), Issledovaniye vliyaniya protsessov predvaritelnoy filtratsii na mutnost piva, Proizvodstvo napitkov, 2, pp. 36-39 (in Russian).

15. Ramasami P., Jhaumeer-Laulloo S., Rondeau P., Cadet F., Seepujak H., Seeruttun A. (2004). Quantification of sugars in soft drinks and fruit juices by density, refractometry, infrared spectroscopy and statistical methods, Afr. J. Chem., 57, pp. 24-27.

16. Tomovska J., Gjorgievski N., Makarijoski B. (2016), Examination of pH, titratable acidity and antioxidant activity in fermented milk, Journal of Materials Science and Engineering, 6(11-12), pp. 326-333.

17. Wang Shiow U., Hsin-Shan V. (2000), Antioxidant activity in fruits and leaves of blackberry, raspberry and strawberry varies with cultival and developmental stage, Journal of Argicultural and Food Chemistry, 2, pp. 140-146.

18. Rojas J., Perea A., Torres Sáez R., Ortiz-López C. (2007), Determination of flavonone compounds in citrus juices by high performance liquid chromatography, Journal of Biotechnology, 131, pp. 130-137.

19. Zubair M., Nybom H., Lindholm C., Rumpunen K. (2011), Major polyphenols in aerial organs of greater plantain (Plantago major L.), and effects of drying temperature on polyphenol contents in the leaves, Scientia Horticulturae, 128, pp. 523-529.

20. Cisowska, A., Wojnicz, D., Hendrich, A.B. (2011), Anthocyanins as antimicrobial agents of natural plant origin, Natural Product Communication, 6(1), pp. 149-156. 
21. Wen, H., Kang, J., Li, D., Wen, W., Yang F., Hu, H., Liu, C. (2016), Antifungal activities of anthocyanins from purple sweet potato in the presence of food preservatives, Food Science and Biotechnology, 25(1), pp. 165-171.

22. Grek O., Pshenychna T., Tymchuk A., Savchenko O., Ochkolyas O. (2020), Research of quality indicators in protein-blueberry concentrates, Potravinarstvo Slovak Journal of Food Sciences, 14, pp. 156-163.

23. Grek O., Pshenychna T., Onopriichuk O., Tymchuk A. (2018), Determination of biologically active substances in protein-berry concentrates, Ukrainian Journal of Food Science, 6(2), pp. 208-216.

24. Grek O., Pshenychna T., Onopriichuk O., Tymchuk A. (2019), Determination of amino acid composition and biological value in protein-berry concentrates, Journal of Hygienic Engineering and Design, 29, pp. 26-32.

25. Martini S., Walsh M.K. (2012), Sensory characteristics and functionality of sonicated whey, Food Research International, 49(2), pp. 694-701.

26. Gullón B. (2009), Prebiotic potential of a refined product containing pectic oligosaccharides, Food Science and Technology, 44, pp. 1687-1696. 